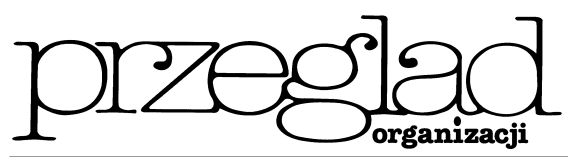

\title{
Analiza czynników wpływu w systemie zarządzania typu project management (PM)
}

https://doi.org/10.33141/po.2005.02.03

Przegląd Organizacji, Nr 2 (781), 2005, ss. 15-18 www.przegladorganizacji.pl Towarzystwo Naukowe Organizacji i Kierownictwa (TNOiK)

\section{Magdalena Rogalska, Zdzisław Hejducki}

\section{Wprowadzenie}

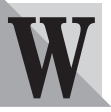
procesie zarządzania według zasad project management [Cleland (1988), Haiman, Scott (1995), Hellriegel, Slocum (1992), Hodge (1991), Kendal (1992), Kerzner (1994), Lessem (1998), Turner (1993), Yeack, Sayles (1996), Van de Merwe (1997)] można ustalić czynniki związane z morfologią zarządzania, mające bezpośredni i pośredni wpływ na efektywność projektu inwestycyjnego [Afanasjev (1995)]. Poszukujac optymalnych algorytmów tworzenia koncepcji, planowania [Afanasjev (1995, 2000, 2002), Hejducki, Mrozowicz (1995, 2001)], realizacji, zakończenia przedsięwzięć, można zastosować uogólnienia dotyczące prakseologii, a w szczególności metodologii projektowania [Czaplinski, Mrozowicz, Musial (1990)]. Stosując np. procedury heurystyczne [Partyka (1996)] do rozwiązywania problemów, napotykamy na trudności wynikające niekiedy z nieprecyzyjnego formułowania problemu. Realizacja obiektów budowlanych wymaga ujęcia i systematyzowania czynników o charakterze inżynierskim, społecznym, ekonomicznym, ekologicznym, niekiedy nawet politycznym, prawnym i innym. Projekty powstają więc w związku z uświadomieniem potrzeb, które należy zaspokoić. Proces zarządzania projektem inwestycyjnym rozpoczyna się więc w momencie pojawienia się potrzeby sformułowania i rozwiązania problemu. W budownictwie może to być czynnik zewnętrzny, np. zapytanie ofertowe, zaproszenie do przetargu, lub wewnętrzny, związany np. z modernizacją systemu komputerowego przedsiębiorstw.

\section{Analiza czynników w systemie zarządzania typu project management}

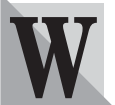

tradycyjnym podejściu project management głównymi czynnikami rozpatrywanymi w realizacji przedsięwzięcia budowlanego są: czas, koszt i jakość.

Przy czym rozumienie jakości odbiega od tradycyjnego, proponowanego przez normy ISO 9000. W rozumieniu norm ISO jakość to produkcja lub wykonanie zgodnie $\mathrm{z}$ oczekiwaniami klienta-odbiorcy. W podejściu project management zakłada się, że odbiorca jest w stanie określić swoje oczekiwania jedynie w fazie użytkowania, nie musi jednak znać się na budow- nictwie i najczęściej nie jest w stanie sprecyzować swoich oczekiwań i żądań dotyczących detali projektowych i wykonawczych.

W niniejszym opracowaniu proponuje się uwzględnienie dodatkowych czynników bezpieczeństwa, zdrowia, środowiska naturalnego, prawa i użytkowalności obiektu jako integralnych w procesie zarządzania przedsięwzięciem budowlanym, czyli w rozumieniu project management - zarządzania projektem.

\section{Czynniki wpływu PM w realizacji projektu budowlanego}

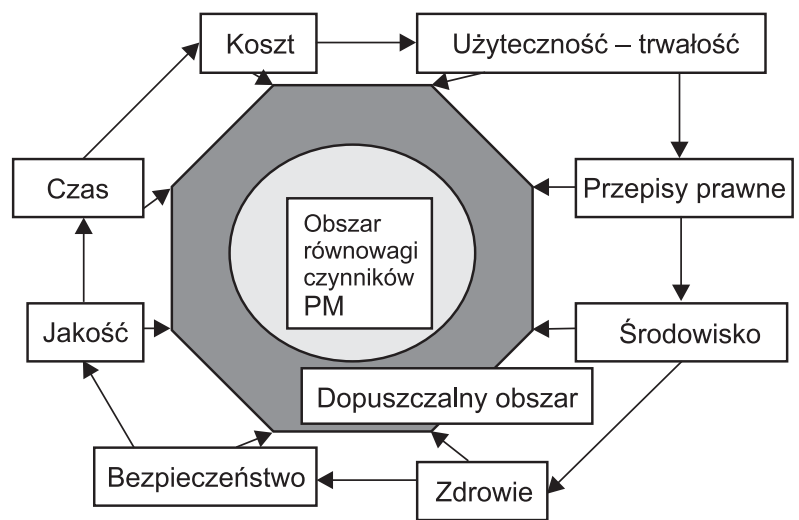

Rys. 1. Układ czynników wpływu w procesie project management

Analizując obszar równowagi czynników PM należy brać pod uwagę różny punkt widzenia poszczególnych uczestników projektu budowlanego. Określenie pełnej równowagi jest w zasadzie niemożliwe, natomiast należy dążyć do kompromisu interesów i nieprzekraczania dopuszczalnego obszaru równowagi czynników PM. Przesunięcie obszaru równowagi czynników PM poza obszar dopuszczalny powoduje naruszenie interesów któregoś z uczestników projektu, a zatem jego niezadowolenie, brak zysku lub straty, brak możliwości sprzedaży lub wynajęcia obiektu budowlanego, uciążliwość użytkowania itp. Niemożliwe jest osiągnięcie założonego celu projektu. Priorytety przyjmowane przez poszczególnych uczestników projektu są różne; każdy koncentruje się przede wszystkim na osiąnięciu swojego własnego celu, który nie zawsze jest identyczny z celem projektu. 


\section{Priorytety inwestora PM}

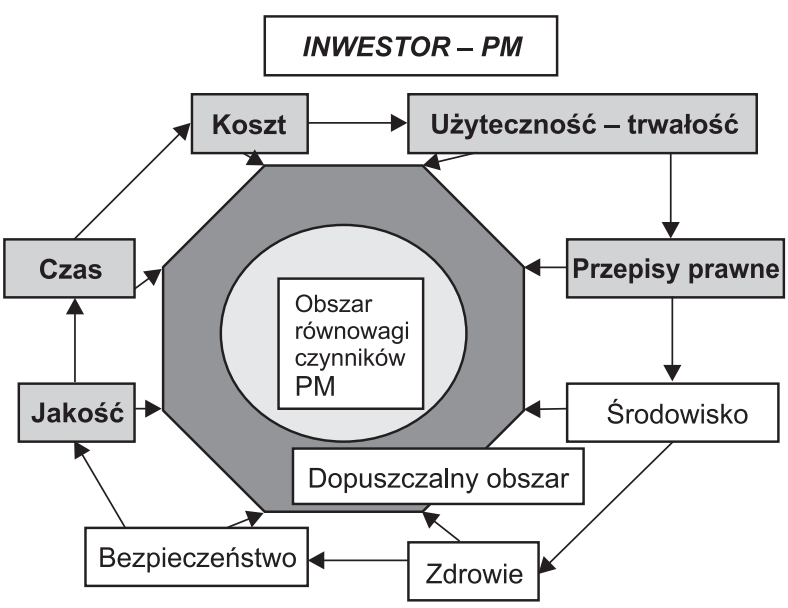

Rys. 2. Priorytetowe czynniki wpływu PM $\mathrm{z}$ punktu widzenia inwestora

W przypadku inwestora, który nie musi być użytkownikiem obiektu budowlanego priorytetowe czynniki (rys. 2) to:

- Koszt - dla inwestora istotne jest obniżanie kosztów do poziomu umożliwiającego osiągnięcie założonego celu, np. budynek zaprojektowany przez o wiele tańszego architekta może okazać się obiektem o tak niskich walorach zarówno funkcjonalnych, estetycznych, jak i ekonomicznych, że stanie się nieużytkowalny, czyli bezwartościowy. Poszukiwanie rozwiązań najtańszych doprowadza po przekroczeniu dopuszczalnego obszaru równowagi czynników do obniżenia jakości, użytkowalności.

- Czas - inwestor deklaruje najbardziej korzystny dla siebie czas wykonania projektu. Inwestor może dążyć do skrócenia czasu realizacji projektu (wtedy zwykle deklaruje posiadanie środków umożliwiających sfinansowanie projektu) niekiedy nie uwzględniając ograniczeń wynikających z procesu projektowania technicznego, wymogów prawnych, zachowania warunków bezpieczeństwa podczas montażu itp. Inwestor może dążyć również do wydłużenia czasu trwania projektu (deklarując to przed przystapieniem do rozpoczęcia projektu bądź w trakcie jego realizacji). Może to być związane z sytuacją ekonomiczną przedsiębiorstwa: zmianami zdolności kredytowych, własnościowymi, koncepcji rozwojowych, czy płatnościami wystawionych faktur.

- Jakość - dotyczy przede wszystkim certyfikacji obowiązkowej na znak bezpieczeństwa „B” użytych materiałów budowlanych, certyfikacji dobrowolnej producentów materiałów budowlanych, bądź aprobat technicznych (materiały te posiadają gwarancje) oraz przedsiębiorstw posiadajacych certyfikat ISO z rodziny 9000 .

- Użyteczność - trwałość - to czynnik zdecydowanie istotny w przypadku, gdy inwestor jest jednocześnie użytkownikiem, natomiast gdy nie jest użytkownikiem i sprzedaje obiekt zaraz po wybudowaniu najczęściej nie jest zainteresowany analizą kosztów eksploatacji. Rozwiązanie pośrednie, czyli sytuacja gdy inwestor buduje obiekt „pod wynajem”, decyduje o dużej wadze problemów dotyczących trwałości budynku (minimalny koszt remontów), natomiast niewielkiej wadze kosztów bieżących eksploatacyjnych.

- Przepisy prawne - stanowia jedynie utrudnienie realizacji projektu, dopóki nie mogą być wykorzystane przez inwestora w obronie swoich racji i wymagań technicznych.

\section{Priorytety projektanta DM}

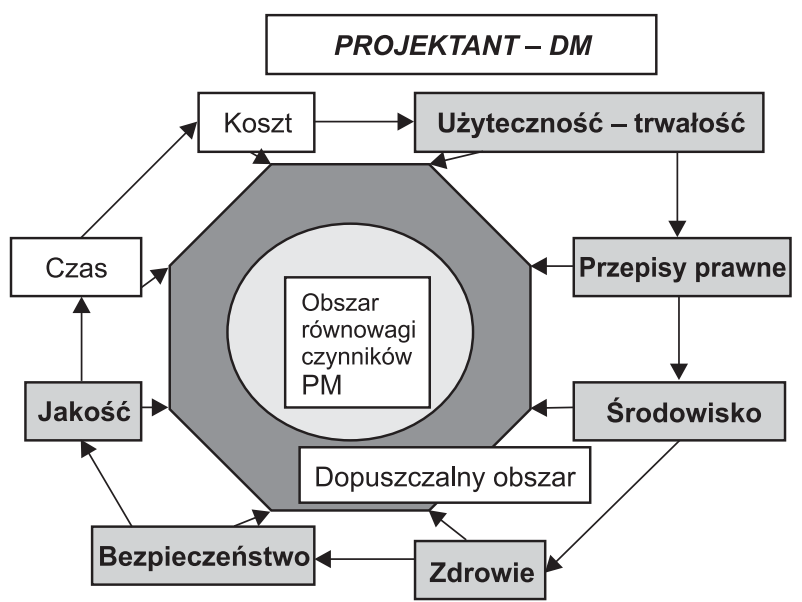

Rys. 3. Priorytetowe czynniki wpływu PM z punktu widzenia projektanta dokumentacji technicznej

- Przepisy prawne - stanowią podstawę wykonania projektu technicznego. Za uchybienia w przepisach projektant odpowiada finansowo i karnie. Zatem projektant jest żywotnie zainteresowany wypełnieniem wymagań prawa, choć nie zawsze jest to zgodne z wolą pozostałych uczestników projektu budowlanego, ponieważ mogą one powodować trudności w realizacji, podnosić koszty przedsięwzięcia, zakłócać ogólny plan pracy lub harmonogramy.

- Użyteczność - jest miara umiejętności projektanta i ma wpływ na jego późniejsze zlecenia oraz przyszłe wynagrodzenia, czyli pozycję na rynku. Projektant musi wypośrodkować wymagania inwestora, który zwykle nie potrafi sprecyzować swoich potrzeb i oczekiwań, oraz wymagania techniczne i technologiczne. Jednocześnie jest to zadanie twórcze, artystyczne związane zarówno $\mathrm{z}$ wypełnianiem znanych $\mathrm{i}$ akceptowalnych kanonów, jak i poszukiwaniem oryginalnych rozwiązań estetycznych bądź nawet łamaniem kanonów.

- Trwałość - trwała i piękna budowla jest wizytówką projektanta.

- Jakość - rozumiana jako jakość dokumentacji technicznej, sposób wykonania dokumentacji rysunkowej i graficznej, koordynacja poszczególnych branżowych zespołów projektowych, umiejętności głównych projektantów, ich doświadczenia.

- Bezpieczeństwo - bezpieczeństwo konstrukcji $\mathrm{w}$ fazie projektowania, wykonania i użytkowania, spełnienie wymagań BHP. 
- Środowisko - projektowanie zgodnie z zasadami zrównoważonego rozwoju .

- Zdrowie - dotyczy akustyki budowli, mikroklimatu, poczucia komfortu, projektowania wykończenia wnętrz w sposób minimalizujący negatywne oddziaływanie, np. z badań prowadzonych przez PZH wynika, że zanieczyszczenie środowiska wewnętrznego w obiektach budowlanych użyteczności publicznej i mieszkalnych wzrosło o $90 \%$ w ciagu ostatniej dekady ze względu na stosowane technologie, techniki, materiały wykończeniowe, środki konserwujące i dezynfekcyjne.

\section{Priorytety wykonawcy CM}

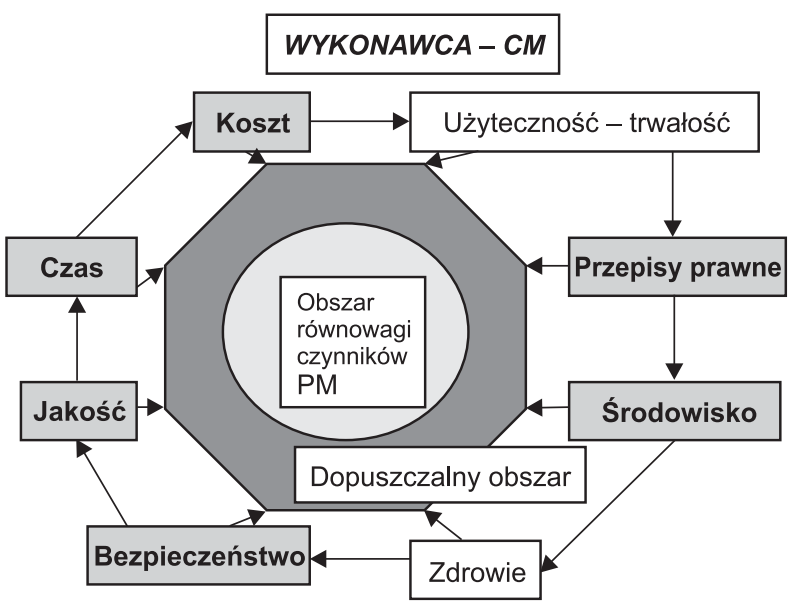

Rys. 4. Priorytetowe czynniki wpływu z punktu widzenia wykonawcy CM

- Koszt - koszty projektu z punktu widzenia wykonawcy są o tyle istotne, że stanowią podstawę naliczania jego zysku. W zależności od sposobu podpisania umowy wykonawca zwykle dąży do obniżenia swoich kosztów, ponieważ od tego zależy jego zysk. Ma to miejsce w przypadku ustalenia ceny ryczałtowej za wykonywane roboty. W przypadku zamówień publicznych ustala się np. ceny jednostkowe za wykonywaną usługę i obmiarem powykonawczym uzyskuje się cenę końcową (ma to miejsce w przypadku robót remontowych, renowacyjnych, konserwacji zabytków, modernizacji).

- Czas - wykonanie projektu w określonym czasie jest podstawowym zadaniem wykonawcy i podwykonawców. Przekroczenie terminu uzgodnionego w umowie może powodować nawet utratę zysku uczestników projektu. Związane jest nie tylko z karami umownymi nakładanymi przez inwestora na wykonawcę, lecz również z utratą ciągłości pracy przez podwykonawców (nie mogą w określonym czasie rozpocząc swoich prac, tracąc przy tym alternatywne zlecenia). W przypadku projektów powtarzalnych przyjmuje się stałe cykle realizacji projektów i zwykle nie są przewidziane negocjacje dotyczące czasu trwania prac. Jest to zadanie trudne w przypadku czynników zakłócających, takich jak: złe warunki atmosferyczne, znaleziska archeologiczne, błędy projektowe i wykonawcze itp., lecz i tak zdecydowanie prostsze w od- niesieniu do projektów remontowych, renowacyjnych zwłaszcza budynków zabytkowych o niepełnej dokumentacji przedwykonawczej. Popularny system planowania projektu CPM/PERT nie zawsze uwzględnia specyfikę budowlaną. Koncentrowanie się na drodze krytycznej powoduje często niezachowanie ciaggłości pozostałych procesów budowlanych. Określanie najwcześniejszych i najpóźniejszych terminów rozpoczęcia i zakończenia prac zapewnia tzw. rezerwy czasu, co w praktyce oznacza przestoje firm albo frontów robót. Dlatego też wydaje się celowe stosowanie takich metod organizacji, które zapewnią uwzględnienie ciągłości pracy podwykonawców lub niekiedy ciągłości wykonania różnych procesów na frontach roboczych. Warunek ten nie jest spełniony w systemie CPM/PERT, którego metodyka dotyczy głównie analizy drogi krytycznej, nie uwzględniając interesów podwykonawców. Założenia probabilistycznego charakteru metody PERT często nie są stosowane w praktyce i nadawany jest im charakter deterministycznego modelu sieciowego. Równocześnie z uwagi na wielką liczbę (nawet kilka tysięcy) zadań w procesie realizacyjnym projektu, model taki jest w praktyce nieczytelny i szybko ulega dezaktualizacji. Stosowane powszechnie komputerowe systemy planowania, np. PRIMAVERA SYSTEMS, SURE TRAK, SPIDER PROJECT i inne służa głównie do przetwarzania wprowadzonych danych, a nie do planowania realizacji. - Jakość - przedsiębiorstwo posiadające udokumentowany system zarządzania przez jakość ma ułatwiony dostęp do pozyskania zleceń. Jeśli system ten nie jest postrzegany jedynie jako dodatkowa uciążliwość, może przynieść wymierne korzyści w postaci zmniejszenia ryzyka powstania chaosu organizacyjnego i błędów decyzyjnych na różnych etapach realizacji projektu. Pozwala to ustrzec się przed samowolą pracowników, zmusza ich do dyscypliny, przestrzegania wymogów technicznych i technologicznych, zmusza do sprawniejszego działania, ułatwia kontrolę na wszystkich szczeblach. Porządkuje dokumentację firmy ułatwiając dostęp do dokumentów. Z drugiej strony wykonawca zobowiązany jest do przestrzegania przepisów dotyczących zakupu i stosowania materiałów posiadających adekwatne dokumenty, takie jak: znak bezpieczeństwa „B”, atest PZH, aprobaty techniczne, deklaracje zgodności itp.

- Bezpieczeństwo - dotyczy przede wszystkim bezpieczeństwa pracowników. Stanowi wymagany prawem element dokumentacji technicznej. Podlega kontroli Państwowej Inspekcji Pracy, która jest uprawniona nie tylko do nakładania kar pieniężnych, ale nawet do wstrzymania budowy. Istniejąca świadomość zagrożenia mienia i ludzi (wysoka wypadkowość w budownictwie) mobilizuje wykonawców do wypełniania przepisów lub też nawet wzmożenia zabezpieczeń w przypadku potencjalnego zagrożenia. Ponadto polisy ubezpieczeniowe pracowników sformułowane są zwykle w taki sposób, że niespełnienie podstawowych warunków BHP powoduje utratę odszkodowania.

- Przepisy prawne - wszyscy zobowiązani są do wypełniania obowiązujących przepisów prawnych. 
Mogą one stać się zarówno czynnikiem zabezpieczającym interes wykonawcy, jak i innych uczestników projektu budowlanego. Oprócz prawa budowlanego i cywilnego wprowadza się przepisy szczegółowe uwzględniające uwarunkowania wykonawcze. Stanowią one treść umów cywilnoprawnych. Wykonawca zainteresowany jest w ustanowieniu szczegółowych zapisów umowy dotyczących warunków płatności, przyszłych roszczeń, gwarancji, rękojmi itp.

- Środowisko - pojawiające się w procesie realizacji projektu toksyczne bądź szkodliwe odpady poprodukcyjne wymagają określonych procedur utylizacyjnych, a zatem dodatkowych nakładów często nie uwzględnianych w kosztorysie przedwykonawczym. Największe zanieczyszczenia środowiska powstają na etapie wznoszenia obiektu budowlanego.

\section{Priorytety użytkownika}

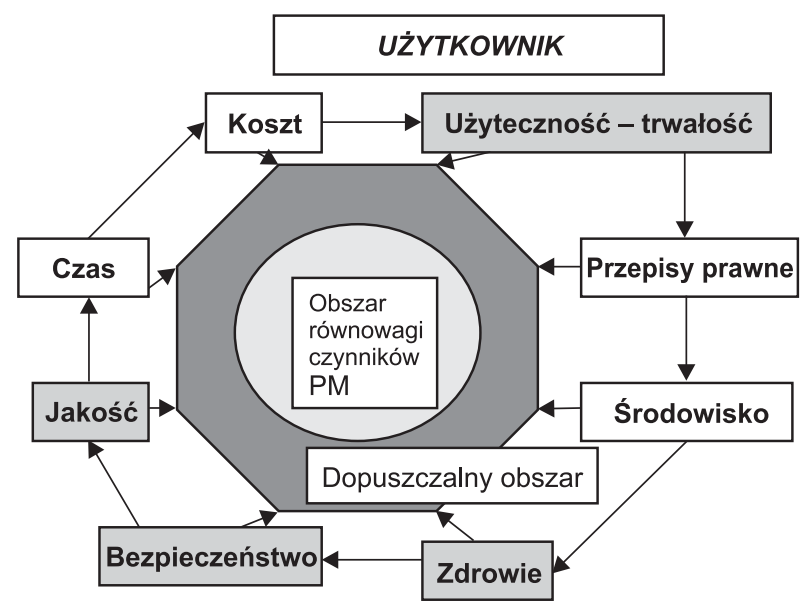

Rys. 5. Priorytetowe czynniki wpływu z punktu widzenia użytkownika

- Użyteczność - z punktu widzenia użytkownika jest to najbardziej istotny czynnik. Użytkownik wynajmuje obiekt budowlany, mieszkanie czy też lokal usługowy spełniający w przybliżeniu jego wymagania. Kryteria są w tym przypadku jednoznaczne. Wprawdzie użytkownik jest zwykle przygotowany na poczynienie pewnych zmian i dostosowanie wynajmowanego obiektu do swoich potrzeb, jednak podstawowe wymogi co do np. powierzchni lokalu muszą być spełnione.

- Bezpieczeństwo - jest warunkiem koniecznym, poczucie bezpieczeństwa jest niezbędne do zachowania komfortu psychicznego mieszkańców. Często nawet spękania gładzi tynkowej odbierane są przez mieszkańców jako zagrożenie.

- Zdrowie - coraz wyższa świadomość społeczna co do toksyczności lub szkodliwości niektórych materiałów budowlanych powoduje, że użytkownicy nie chca w swoich domach materiałów uznanych za niepewne.

- Jakość - użytkownik określa przede wszystkim swoje możliwości finansowe i oczekuje wysokiej jakości na swoją miarę. Oczekuje prawidłowego wykona- nia prac budowlanych, nawet jeśli prowadzone są one w niskim standardzie.

\section{Podsumowanie}

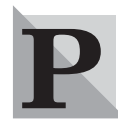

rzeprowadzona analiza może dowodzić, że pomijanie znaczenia określonych czynników, tj. np. ważności uwzględniania warunków prawnych lub użyteczności, ma wpływ na efektywność projektów inwestycyjnych. Dotychczas badane i analizowane czynniki wpływu, tj. koszt, czas i jakość, nie zapewniają pełnego udziału interesów uczestników projektu budowlanego i nie zapewniają właściwej równowagi obszaru wpływu.

dr inż. Magdalena Rogalska Politechnika Lubelska dr hab. inż. Zdzistaw Hejducki

Politechnika Wrocławska

\section{BIBLIOGRAFIA}

[1] AFANASJEV V.A., Petersburskaja szkota upravlenija projektami, International Symposium Project Management St. Petersburg 1995.

[2] AFANASJEV V.A., AFANASJEV A.W., HEJDUCKI Z., Problemy realizacji kompleksów mieszkaniowych $w$ Rosji, „Kalejdoskop Budowlany”, 2/2002.

[3] AFANASJEV V.A., AFANASJEV V.A., Potoćnaja organizacja rabot $v$ stroitielstvie, St. Petersburg 2000.

[4] A Guide to the Project Management Body of Knowledge, Upper Darby, PMI Standards Committee, Project Management Institute 1996.

[5] CLELAND DI/KING WR, (red.), Project Management Handbook, New York: Van Nostrand Reinhold 1988.

[6] CZAPLIŃSKI K., MROZOWICZ J., MUSIA乇 W., Podstawy metodologii projektowania $w$ budownictwie, Wrocław 1980.

[7] HAIMANN T., SCOTT W.G, CONNOR P.E., Management, Boston: Houghton Mifflin 1985.

[8] HEJDUCKI Z., MROZOWICZ J., Stream Methods of Construction Work Organization, „Engineering, Construction and Architectural Management”, 8/2001.

[9] HEJDUCKI Z., MROZOWICZ J., The Problems of Row Structure Flow Modeling, International Symposium Project Management, St. Petersburg 1995.

[10] HELLRIEGEL D., SLOCUM J.W., Management, USA: Addison-Wesley 1992.

[11] HODGE B.J., ANTHONY W.P., Organisation Theory, Massachusetts: Allan and Bacon 1991.

[12] KENDAL K.E., KENDAL J.E., Systems Analysis and Design, New Jersy, Prentice-Hall 1992.

[13] KERZNER H., Project Management, New York: Van Nostrand 1994.

[14] LESSEM R., Global Management Principles, New York, Prentice Hall 1989.

[15] PARTYKA M., Wybrane zagadnienia logiki i heurysty$k i$ w inżynierii projektowania $i$ zarzadzania, Oficyna Wydawnicza Politechniki Opolskiej 1996.

[16] TURNER J.R., The Handbook of Project-Based Management, McGraw Hill 1993.

[17] YEACK W., SAYLES L., Virtual and Real Organisations: Optimal Paring, PM Network, Project Management Institute, sierpień 1996.

[18] VAN DER MERWE, Multi Project Management, „International Journal of Project Management”, sierpień 1997, Vol. 15, nr 4. 